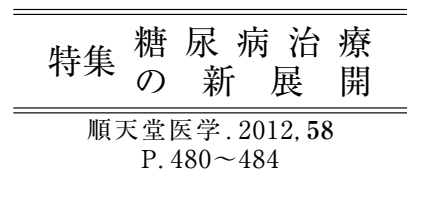

患者をその気にさせる糖尿病診療のテクニック**

\author{
弘世 貴 久*
}

\begin{abstract}
高血圧, 脂質異常症, 糖尿病は 3 大生活習慣病と呼ばれている. 高血圧, 脂質異常症は治療薬の進歩によりそ の治療はかなり目標到達が容易となった。一方糖尿病はというと, どんな優れた内服薬を用いても食事や運動療 法を施行しない患者では血糖コントロールの改善は望めない. 最近ではエンパワーメントといった患者中心主義 の方法論が紹介されているが $\left(\right.$ 表-1) ${ }^{1)}$ なかなか現実的な指導に生かしていくのはまだまだ難しく感じる. そこで 本稿では患者の治療意欲を高めるためのコツをエビデンスからではなくあえて筆者の経験よりご紹介したい. ひ とつは食後高血糖の治療, もうひとつはインスリン治療の導入と血糖自己測定の開始夕イミングについてであ る.

キーワード : 食後高血糖, 自己決定理論, インスリン, 外来導入, 血糖自己測定
\end{abstract}

\section{食後高血糖}

食後高血糖が大血管症のリスクとなるといわれだ したのは1990年代の後半である ${ }^{23)}$. 血糖の上下の振 幅が大きいと血管への酸化ストレスが上昇し, 動脈硬 化に至るというストーリーが基礎研究でも証明されて いるようである. しかし，この食後高血糖，はたして 実際の診療の場でどの程度真剣に介入できているのだ ろうか?（表-2）食後という状況は空腹時と違って食 べたものも食べた後の時間もまちまちでなかなか客観 的評価が難しくなる. 今でもかなりの医師，しかも糖 尿病の専門医ですら通常の診察時採血に空腹を義務付 けているのを目にするが，おそらくこのこと自体が食 後高血糖に医師の眼が向いてない証であろう，食後高 血糖を測ることが患者の食事療法, 運動療法, そして 内服薬服薬のアドヒアランス向上に寄与すると私は信 じている.

\section{血糖値は食べてきて測る！ 食べたものを聞く！ からはじめる}

毎回, 外来診療の際，ほとんどすべての糖尿病患者 は血糖值と HbA1cを計測している. しかし, 血糖值 については空腹でない限り多くの医師は患者にコメン トすることなく食事の影響を受けない $\mathrm{HbAlc}$ の上下 で今のコントロールが良いとか悪いとか説明してい る。それなら初めから血糖值なと測らなければよいの

\footnotetext{
* 東邦大学医学部内科学講座糖尿病 - 代謝 - 内分泌学分野 **第 328 回順天堂医学会学術集会 [Sep. 13, 2012 開催〕

〔Oct. 23, 2012 原稿受領〕
}

表-1 エンパワーメント

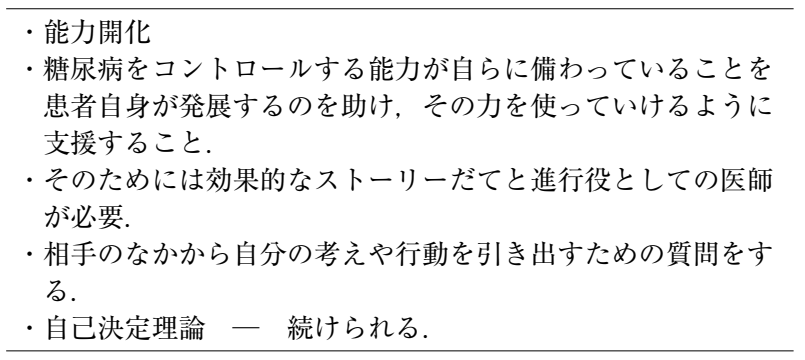

表-2 本当に食後高血糖にホンキで対応してきたか？

・空腹時血糖を測るのはもうやめよう!

・食後 1 時間, 2 時間どちらが大事?

・食べたものを必ず聴取．かなりの高齢でもさっき食べたもの は覚えている。

· 5 分診療で相談に乗れるのはせいぜい 1 食分.

・まずはバランスの指導から.

・食後の血糖值をネ夕に食事と時間と血糖值の関係を患者と一 緒に考えれば食事療法に身が入る。

である．血糖值を測ったら必ずそこに「魂」を入れな ければならない．私はほとんど午前の外来を担当して いることが多いので患者にはいつも食べている朝食を 摂ってきてくださいとお願いしている。 この時点で朝 食を摂らない人が「あぶりだされて」くる．朝食を摂 らない人のほとんどが前の晚の過食が認められる．食 べてきてくれたら次に食後何時間か？ そして何を食 べてきたかを問う． 2 時間血糖值が $180 \mathrm{mg} / \mathrm{d} l$, Lか し何を食べたかでまったくこの值がもつ意味は変わっ てくる.ご飯軽く一膳, 納豆に野菜たっぷりの味噌汁. これで $180 \mathrm{mg} / \mathrm{d} l$ あれば食後高血糖の治療として内服 薬の検討も必要かもしれない. ところがパン 2 枚とバ 
インスリンの効能や合併症の

恐ろしさを語っても成功率は低い

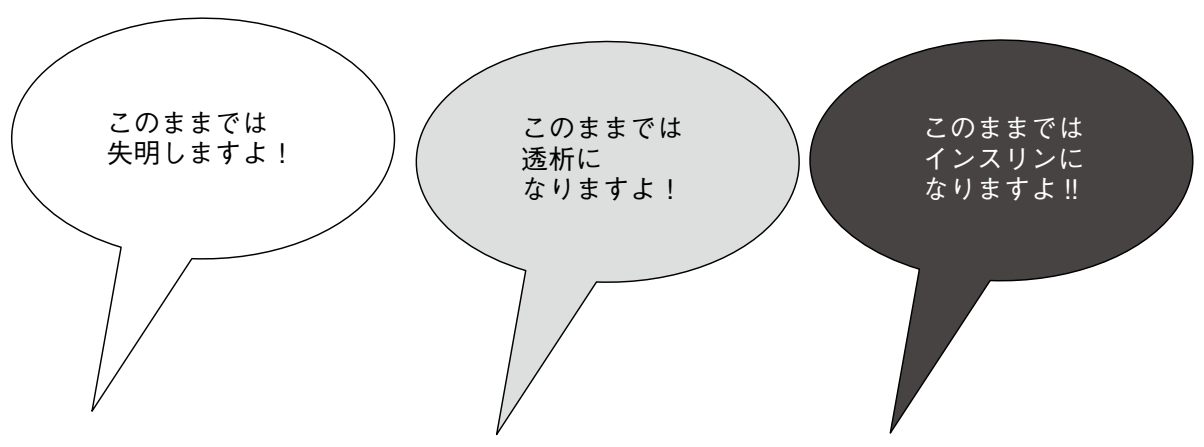

図-1 何度も脅しを使ってきませんでしたか？

ナナ1本と野菜ジュースだとすると, クスリを飲む前 に改善しなければならないことがあるのがわかる．野 菜ジュースは多くの患者が野菜がわりに摂るケースが 多いのだが，ショ糖が多く含まれているので要注意の 食品である. そこで患者には野菜ジュースをやめても らい，野菜サラダや煮物に切り替えてもらう。そして 再度食後血糖值を同じタイミングで測る. 血糖值の改 善を患者と分かち合う. 生の血糖值の改善を体感する ことによって，おそらく野菜ジュースはやめてもらえ るであろう. 内服薬にしてもこれまで HbAlcの改善 で患者に話をしていたが，各食前に飲まなければなら

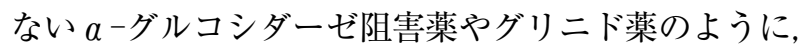
どうしても服薬アドヒアランスの上がりにくい薬をき ちんと飲んでもらうには，このような血糖モニター （飲んだときと飲んでいないときの血糖値を比較する） が扮勧めである．効果を実感することがどんな医師の 説明よりもアドヒアランス改善に寄与するといえるで あろう。

\section{インスリン導入の説得 〜最もやる気にさせるのが難しいステップ}

インスリン導入は何より患者の導入への理解を得 ることができないと, いかに簡単であろうが前に進ま ない，もう一度その点を考えてみてほしい。これまで インスリン導入の理解を求める方法を専門書でみる と，ほとんどの場合インスリンの有効性や不良な血糖 コントロールをそのままにすることのリスク，すなわ ち合併症の進行について我慢強く説明して納得しても らうというのが一般的であった. しかし, 多くの医療 従事者に身に覚えがあるかもしれないが，まだインス リンを必要としない段階の 2 型糖尿病患者で血糖コン トロールを乱してしまったとき「このままではインス リンになりますよ!」と言って脅かしていなかったで あろうか (図-1）？これは明らかにインスリン治療
をネガティブなものと想定しているわけで，失明する とか透析になりますよといって脅かしているのとさし て変わらないのである，そんな風にいわれてきた患者 はいくらインスリンが素晴らしい治療だと説得されて も絶対いやだということになるであろう。ですから， 普段からインスリン治療を脅し文句に使わないように 心がける必要がある。

もう一点, インスリン治療を説得するとき患者の口 から出てくる決まり文句は「インスリンなんかはじめ たら一生やめられないからいやだ!」ではないだろう か? インスリンは本当にやめられないのだろうか? こういう質問をされたときに私たちは以前，「インス リンで治療して良好な血糖コントロールを継続すれば やがて膵 $\beta$ 細胞が息を吹き返してインスリンから内服 薬に戻せます」と説明してきた。しかし，実際には長 年経口薬を内服しても血糖コントロールが不良であっ た患者はたとえインスリンを用いて良好な血糖コント ロールを実現しても再び経口薬に戻すことができる可 能性は極めて少ないと考えられる。ここでいう離脱と はインスリンで着いていたのと同じくらいのレベルの 良好な血糖コントロールがキープできる場合を指して いる. しかし, 患者は「離脱できない」=「癖になる」「依 存性ができる」というように考えている場合が多い. 実際にインスリンを導入しても「癖になる」「依存性が できる」ことがないのは専門医ならずとも承知してい ることである．糖尿病は内分泌疾患の一つである， ほ かの内分泌臓器では，たとえば副腎皮質ホルモンを長 年投与していると副腎皮質自体が萎縮して機能低下を 起こす可能性があるが, 膵 $\beta$ 細胞はインスリンを投与 するとむしろ「休ませる」ことができて機能が高まる 場合すらある.つまりインスリンを開始してもしいや になったという理由でインスリン治療をやめたらどう なるのだろうか？ 答えは図-2に示すように悪化す るのは確かであるが，インスリン治療をはじめたとき と同じレべルか糖毒性の改善により少し良くなるので 


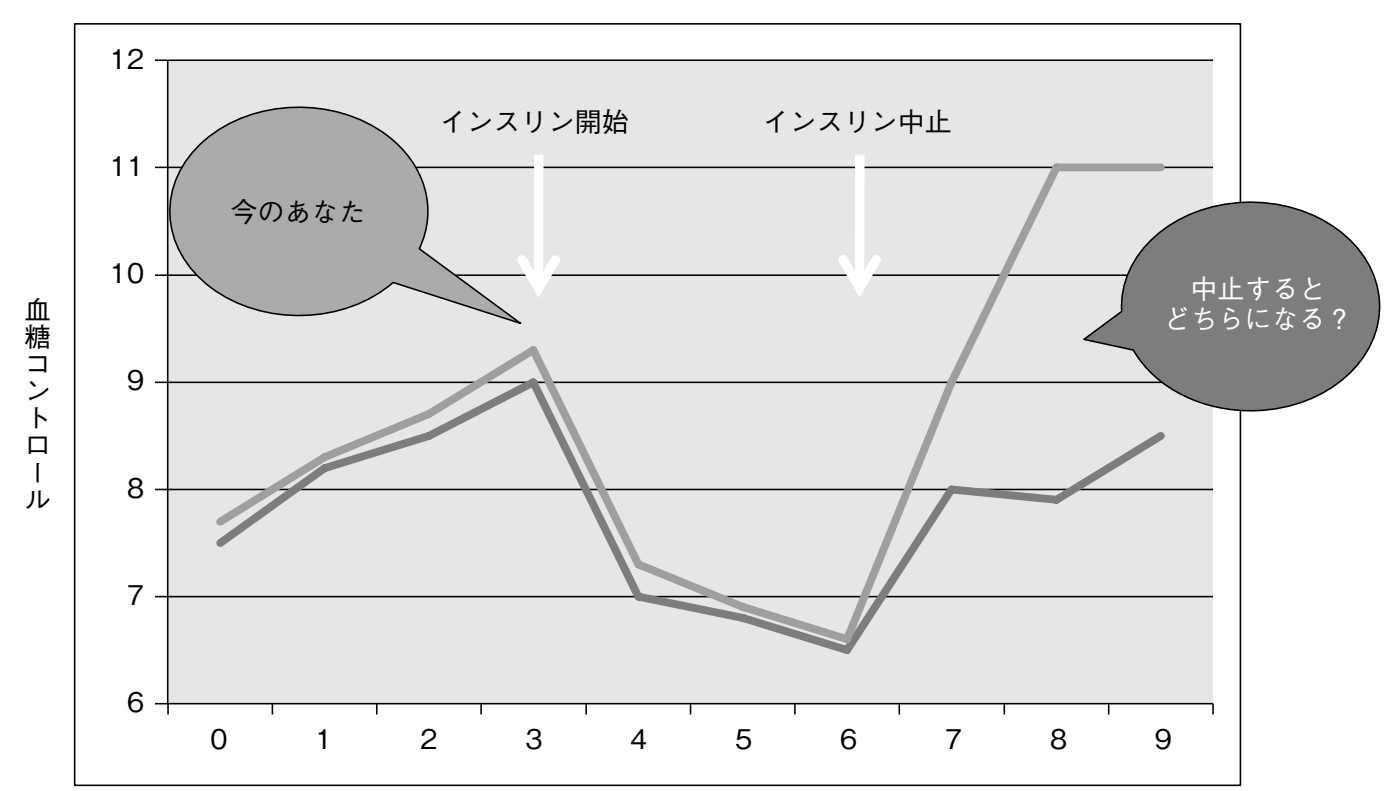

図-2 今のあなたとは？ インスリンでよくなったコントロールはやめるとどうなるか？

表-3インスリン治療を锥めると必ず出てくる患者さんからの質問と医師の答え インスリンはいったんはじめたら 一生やめられないんでしょう！？

インスリンをはじめることで血糖コントロールがよくなり

膵 $\beta$ 細胞がまた元気を取り戻せばお薬に戻すことだって可 能です。

ある. 患者にはインスリンをやめても「今のあなたに 戻るだけです」と説明するようにしている(表-3)。「今 のあなた」というのは拈そらく $\mathrm{HbA1} \mathrm{c}$ はかなり不良 であろうが，症状はまったくなく，むしろ毎日，お腹 が空いて困る健康感のそこなわれていない「あなた」 である.きっと安心してとにかく受け入れてもらえる のではないだろうか (図-2).

さて，そうはいっても眼の前にいる患者にどうやっ てインスリン導入を説得するかということは「百聞は 一見にしかず」である．インスリン注射を実際に患者 に体験してもらうことで「あっ！全然痛くない！」 と眼からウロコが落ちたように納得してもらえるので ある．なぜこんな単純な方法が奏効するのか？ とい う理由は以下の通りである。糖尿病患者はいつも外来 受診のたびに血液検査のために採血をする．採血の針 は21Gや $22 \mathrm{G}$ といった太い物で, 患者はこの針を使っ てインスリン注射をするものと思っている場合が多い のである．ささらに糖尿病患者が外来受診の際に毎回行 う採血は，駆血帯を巻いて静脈に針を立てる，痛いだ
けでなく技術的にもかなり難しそうである．熟練した ナースですら「はずす」ことがあるわけだから素人の 自分になどできるわけがない，ということになる，も うどんどんインスリンなど頭からやる気がないという 方向に一人歩きしてしまうのである. 実際, 私が行っ た 24 例の 2 型糖尿病患者のインスリン外来導入前ア ンケートではほとんどの患者がインスリン注射という ものを知らなかったと答えている $(\text { 図-3 })^{4)}$. もし, 自 分でインスリンの注射針をお腹に刺したことがないよ うなら，患者にトライする前に必ずやってみてほし い、そうすれば患者にインスリンを説得するときとて も説得力が出る. なにより最初に主治医が自分のウロ コを落としておくのが第一歩であろう。

\section{血糖自己測定はいつはじめるのか？}

私はかねてから血糖自己測定をインスリン導入と 同時にはじめる必要はないと説明してきた，その理由 は当然,インスリン注射を覚えるときに血糖測定も同 


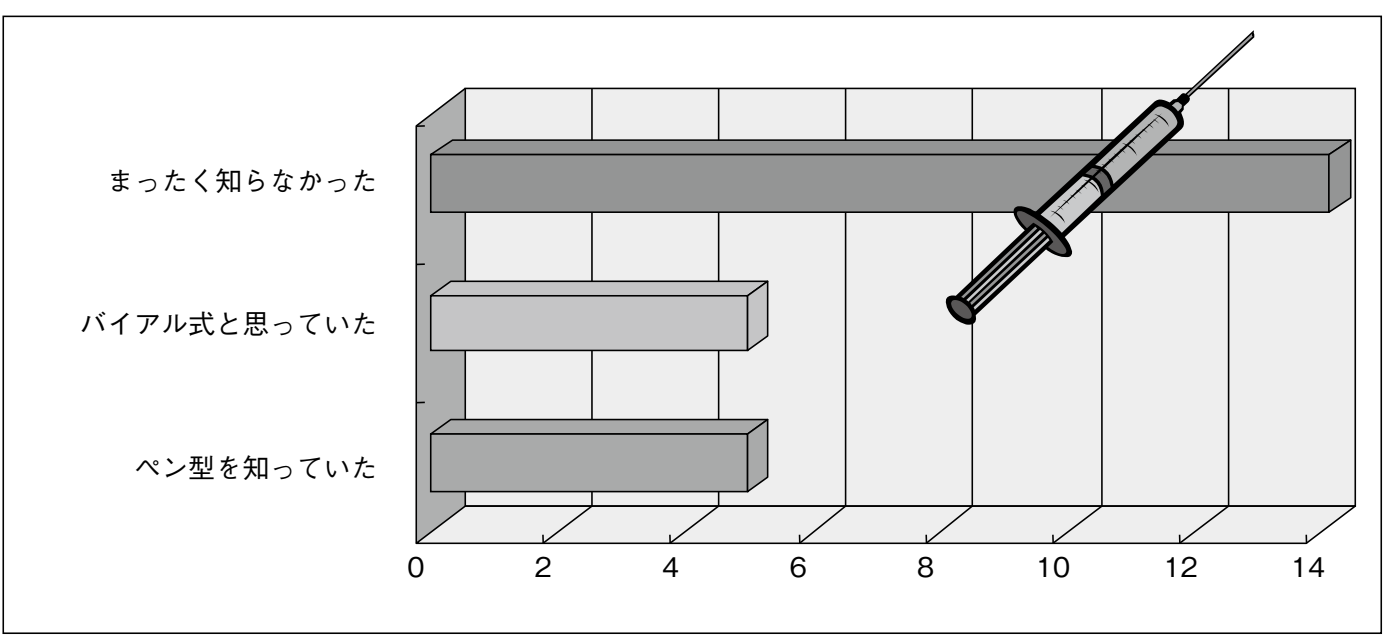

図-3 インスリン注射を嫌がる患者は意外にインスリン注射を誤解している

時に指導すると煩雑で混乱を招くおそれがあるからで ある。しかし理由はほかにもある。穿刺に伴う痛みは インスリン注射のそれより遥かに強い。私はインスリ ンの外来導入を患者に納得してもらうために実際に注 射針を患者に経験してもらって「痛くない」ことを体 験してもらうょうにしていると前項で説明した．しか し「痛くない」注射針で安心した後, これもやらなけ ればなりませんと言って「痛い」血糖測定の穿刺を行 うと, せっかく OKしたインスリンの導入を反故にし てしまうおそれが出てくる.しばらくしてインスリン に慣れて血糖值も知りたいとモチベーションが湧いて きた頃に血糖測定をはじめるのがよいと思う。この記 載を読まれたある先生から血糖測定の穿刺を指の「腹」 ではなく横のほうでやれば痛くないですよ，と㧍教え いただいて実際私もチャレンジしてみた。しかし, 実 際やってみると残念ながら「痛かった」. もちろん腹 でやるよりいくらかましだったが「痛くない」という ことはなかった．これは血糖測定の意味を理解してい る私ですら思うわけであるから，インスリンを導入す ることになっていやだなあと思っている患者では明ら かに「痛い」はずである.やはりこういう論議は自分 で痛いと思うかどうかではなくて，現場で患者がどう 思うであろうかと想定してみなければならないと思 う.

さらに最近多くの非専門医にもたれるようになっ たインスリンの導入法, BOT (Basal supported Oral Therapy）は, 3 回注射法と比較して血糖自己測定を はじめるタイミングがさらに遅くてもよい方法といえ るであろう。この導入法では主に朝食前血糖值を $110 \mathrm{mg} / \mathrm{d} l$ を目標に基礎インスリンを増量していく. 3 回注射だとある程度低血糖の可能性も出てくる用量 まで増量してくると, 各食前それぞれのインスリン量 を次の食前あるいは眠前の血糖值をみて増減すること
になる。そうなるとやはり診療所にそれぞれ来ても らって血糖值を測るわけにはいかない。ところが BOTで導入した場合は診療所に仕事前に来てもらい 1 回測って高ければ1〜2単位増やしましょうというこ とが可能である。この点からも BOTは間の低いイン スリン療法といえるであろう ${ }^{5)}$.

血糖自己測定をしている患者のなかには，毎日7回 測って 1 回の診療で測定チップを 10 箱くらいくださ い，という人がいるのは多くの医師が経験していると 思う。そういう患者に限って血糖值は決して良好とは いえない，それだけ頑張って測るのならばその努力を 食事や運動療法にまわしてくださいと打願いすると, 「いや，測らないと不安なんですよ」といわれるので ある. 以前はインスリン療法には血糖測定が必須とい われていた，しかし，患者はあまり意味がわからない うちからインスリン注射と血糖自己測定をはじめてし まい，まさに条件反射のように血糖值を測定している のかもしれない，そういう人に限って血糖測定は 1 日 おきでいいですよといったらインスリン注射も1日お きになるという，笑い話ではすまないことも実際に経 験した．そのためインスリン注射をまずはじめて血糖 自己測定は指示せず（最初から測るとまだ少量のイン スリンなのであまりよくならないので実は測ってほし (ないという気持ちもある), 外来受診時に測定器を 用いてそのときだけ血糖測定を行う。そうしているう ちにある程度コントロールがついてきたら, 患者のほ うから「この便利な器械, 自宅でもできませんか?」 とリクエストがあるかもしれない。これはまさに待ち に待った瞬間である。患者が自分の血糖值に興味を もった瞬間なのだ，自ら血糖値を測りたいと希望す る，すなわち自分で決めたことはしっかり実行しても らえるし，これが食事療法や運動療法実行への引き金 にもなる．こうやって自分の意思で血糖測定をはじめ 
た患者では「カツ井負荷試験」などを勝手にやって， これはかなり血糖が上がりやすいメニューだから今後 控えよう，といったように自ら試行錯誤をして良好な 血糖管理ができるように工夫するようになる，逆にイ ンスリンと同時に「わけがわからないうちに」血糖測 定を指示された患者では前述のように血糖值を「測っ ているだけ」になってしまうのである.

\section{おわりに}

2型糖尿病の治療のコンセンサスとして，2012年春 に米国および欧州糖尿病学会から発表されたステート メントのなかで注目されているのが「患者中心主義」 である. 治療の決定の過程で患者の意見を取り入れ， あくまで最終決定者は患者である，としている．コン トロールの指標も患者の価值観まで考えたうえで決定 するべきであると述べている，しかし，これは食事療 法はまったく行わず，「俺はポックリ逝くほうがいい から食事療法なんてやらないよ」と言っている問題患 者を放っておいてもよいという意味ではない. 本稿で 述べたごとく治療のステップ，ステップで患者と様々 な情報を共有し，そこから患者の価值観のなかに糖尿
病のコントロールのやる気を芽生えさせることに患者 中心主義の本当の意義があるのではないかと考える.

\section{文献}

1）門脇 孝監訳, 大橋 健訳: 糖尿病エンパワーメント 101 のコッ. 東京 ; 医歯薬出版, $2005: 1 \sim 143$.

2) The DECODE Study Group, on behalf of the European Diabetes Epidemiology Group : Glucose tolerance and mortality : comparison of $\mathrm{WHO}$ and American Diabetes Association diagnostic criteria. Lancet, 1999 ; 354 : 617 621.

3) Tominaga M, Eguchi H, Manaka H, et al : Impaired glucose tolerance is a risk factor for cardiovascular disease, but not impaired fasting glucose. The Funagata Diabetes Study. Diabetes Care, $1999 ; 22:$ 920 924.

4) 弘世貴久, 開まゆ子, 岩田真由美, ほか: 超速効型インス リンを用いた 2 型糖尿病患者の外来インスリン導入の試み. プラクティス, $2004 ; 21: 85 \sim 90$

5) 弘世貴久 : 続これなら簡単今すぐできる外来インスリン導 入. 東京：メディカルレビュー社, 2009.

\title{
HOW DO YOU MOTIVATE YOUR PATIENTS TO KEEP APPROPRIATE GLYGEMIC GONTROL ?
}

\author{
TAKAHISA HIROSE* \\ * Department of internal Medicine, Division of Diabetes, Metabolism, and Endocrinology, Toho University \\ FACULTY OF MEDICINE, TOKYO, JAPAN
}

\begin{abstract}
Recent medical progress in drugs has enabled appropriate control for hypertension and dyslipidemia. On the other hand, diabetes mellitus, another life style mediated disease, is difficult to be managed without improvement of the life style of the patients by themselves. In this lecture, the strategy is introduced to motivate the diabetic patients to keep appropriate glycemic control.
\end{abstract}

Key words : postprandial hyperglycemia, insulin therapy, out-patients, SMBG 